\title{
Irish Pro-Migrant Nongovernmental Organizations and the Politics of Immigration
}

\author{
Pauline P. Cullen
}

Published online: 13 March 2009

(C) International Society for Third-Sector Research and The John's Hopkins University 2009

\begin{abstract}
In this article social movement theory is used to assess the strategic repertoire of a relatively new sector of nongovernmental organizations (NGOs) advocating for migrants rights in Ireland. Pro-migrant NGOs are majority community-led and face a challenging political and societal context for mobilization including a restrictive immigration regime, political and media discourse that racializes migrants, weak public support for the expansion of migrants' rights, and high rates of discrimination and social exclusion experienced by migrant communities. A competitive funding environment also inhibits pro-migrant NGOs capacity to work with emerging migrant-led organizations that simultaneously compete for state and foundation funds. Pro-migrant NGOs in Ireland have responded with a three levelled strategy, namely alliance building with sympathetic public officials and service and information provision to state bodies, campaigns contesting negative media and societal framing of migrants, and networking with transnational NGO coalitions working on immigration issues.
\end{abstract}

Résumé Dans cet article, la théorie du mouvement social est utilisée pour évaluer le répertoire stratégique d'un secteur relativement nouveau qui fait valoir les droits des immigrés en Irlande par le biais des Organisations non gouvernementales. Celles-ci sont en faveur de l'émigration recevant l'aval des communautés et font face à un défi du contexte politique et social stimulant y compris un régime d'immigration restrictif, un discours politique médiatisé qui a tendance à marginaliser les émigrés, un appui du public sporadique en ce qui concerne l'extension des droits des immigrés et beaucoup de discrimination et d'exclusion sont endurées par les émigrés. Un environnement de financement compétitif empêche également la possibilité aux organisations non gouvernementales en faveur de l'immigration de

P. P. Cullen $(\bowtie)$

Department of Sociology, Dickinson College, P. O. Box 1773,

Carlisle, PA 17013, USA

e-mail: cullenp@dickinson.edu 
travailler de pair avec les organisations menées par les émigrés qui rivalisent simultanément avec l'état et les fonds nécessaires. Des Organisations non gouvernementales en faveur de l'immigration en Irlande ont répondu par une stratégie à trois niveaux : (1) La mise au point d'une d'alliance avec des fonctionnaires publics compatissants et le service et l'information prévisionnelle destinée aux corps étatiques. (2) Des campagnes contestant la négativité des médias et l'encadrement social des émigrants. (3) Et enfin la constitution de réseaux de coalitions d'Organisations non gouvernementales transnationales travaillant sur les questions des problèmes suscités par d'immigration.

Zusammenfassung In diesem Artikel wird die Theorie der sozialen Bewegung genutzt, um das strategische Repertoire eines relativ neuen NGO-Sektors, der sich für die Rechte von Migranten in Irland einsetzt, zu bewerten. Pro-migrant-NGOs sind mehrheitlich von lokalen Gemeinschaften geführt und stehen einem schwierigen politischen und gesellschaftlichen Kontext für die Mobilisierung gegenüber, inklusive restriktivem Immigrationsregelwerk, politischem und medialem Diskurs, der Migranten rassifiziert, schwacher öffentlicher Zustimmung für eine Ausweitung der Rechte von Migranten und hohen Raten von Diskriminierung und sozialem Ausschluss von Migrantengemeinschaften. Ein umkämpftes Finanzierungsumfeld blockiert auch die Fähigkeit von pro-migrant-NGOs, mit aufstrebenden von Migranten geführten Organisationen zu arbeiten, die simultan um Gelder von Staat und Stiftungen konkurrieren. Pro-migrant-NGOs in Irland haben mit einer Strategie auf drei Ebenen geantwortet, nämlich Bündnisschließung mit sympathisierenden Amtsträgern und Bereitstellung von Service und Informationen zu staatlichen Institutionen; Kampagnen, die die negativen Medienberichte über und gesellschaftliche Einrahmung von Migranten anfechten und Pflege von Beziehungen zu grenzüberschreitenden NGO-Koalitionen, die an Immigrationsfragen arbeiten.

Resumen En este artículo se utiliza la teoría del movimiento social para valorar el repertorio estratégico de un sector relativamente nuevo de ONG que luchan por los derechos de los emigrantes en Irlanda. Las ONG defensoras de los emigrantes están encabezadas mayoritariamente por comunidades y afrontan un difícil contexto político y social para la movilización, como un régimen de inmigración restrictivo, un discurso político y de los medios racista con los inmigrantes, escaso apoyo público para la difusión de los derechos de los emigrantes y altas tasas de discriminación y exclusión social entre las comunidades de emigrantes. El competitivo entorno de financiación también frena la capacidad de las ONG pro-emigrantes para trabajar con las organizaciones emergentes lideradas por emigrantes que también compiten por la financiación del estado y de fundaciones. Las ONG pro-emigrantes en Irlanda han respondido con una estrategia de tres niveles, a saber: el establecimiento de alianzas con funcionarios públicos compasivos, la disposición de servicios e información para los organismos del estado, campañas para responder a los medios contrarios y marcos sociales de emigrantes, así como redes de coaliciones trasnacionales de ONG que trabajen en cuestiones relacionadas con la emigración. 
Keywords Immigration - Migrants rights · Ireland - Social partnership · Pro-migrant NGOs · European Union

\section{Introduction}

Research suggests that state policy can facilitate or inhibit the integration of migrants, asylum seekers, and refugees into host societies. States also provide the resources for nongovernmental organizations (NGOs) to support the integration of migrants through the provision of advice and services. NGOs can provide a means for governments to consult migrants and ensure a fit between policies, programs, and migrants' actual needs. Notably, they have the potential to provide migrants, asylum seekers and refugees a say in the development of policies for their integration (Spencer 2005, pp. 4-5). Ireland provides an important case study to examine the quality of representation available to migrants, asylum seekers, and refugees and the capacity of NGOs to represent their migrant constituents. ${ }^{1}$ The proportion of immigrants resident in the state has doubled since 2003 and has pushed the population to a high of 4.2 million, a number not seen since the prefamine era. Opportunities have opened up for labor migrants to live and work in Ireland and others have secured residence as refugees or dependants. However, NGOs have highlighted concerns about the treatment of some migrants and their living and working conditions and have sought to influence government policy to provide greater protection for migrants in immigration, employment, and welfare policy. ${ }^{2}$ International bodies have also voiced concerns about the current direction and implementation of Irish immigration policy, which is largely labor-driven with different standards of treatment for high-skills versus low-skills migrants and a defensive and punitive posture towards asylum seekers and refugees (Amnesty International 2006; Council of Europe 2006; UNHCR 2008).

Immigration has brought increasing diversity to Irish society and has raised questions about the construction of national identity, patterns of social stratification, and how the state regulates political and civil rights (Crowley et al. 2006; Loyal 2007; Menz 2008). Accompanying these shifts has been the rapid deployment of a pro-migrant NGO industry in Ireland led by Irish born staff and dependent in part on international foundation and domestic charitable support. ${ }^{3}$ Two national NGOs established to advocate for migrants discussed here, the Migrants Rights Center of Ireland (MRCI) and the Immigrant Council of Ireland (ICI), originated from religious charitable organizations and were facilitated by international foundation

\footnotetext{
1 Ireland and Irish refers to the Republic of Ireland.

${ }^{2}$ Citizens of European Union (EU) member states have the benefit of freedom of movement under the Treaty of Rome and EU law and may live and work legally in Ireland or anywhere else in the EU without a visa. Similarly citizens of Iceland, Liechtenstein, and Norway (members of the EEA, the European Economic Area) do not require any visa to live and work in Ireland. But for non-EU or non EEA citizens, two paths are available to legal residence in Ireland, securing a job with an Irish employer who has obtained a work permit or by claiming asylum.

3 The term pro-migrant NGO is borrowed from the work of Statham and Gray (2005) on migrant advocacy organizations in the United Kingdom.
} 
support from the American based foundation-the Atlantic Philanthropies. While the MRCI and the ICI have established themselves as the principal NGO interlocutors with the Irish state on immigration, a tradition of cooperative relations between NGOs and state bodies has led some to argue that project support and the (nominal) advisory role the state accords to NGOs, limits the independence of such organizations (Murphy 2002; Geoghegan and Powell 2006).

Pro-migrant NGOs have entered into a division of labor with the state to provide services to migrants which has led to a critique that their advocacy efforts are necessarily undermined by their connections to the "racial state" (Lentin 2007). Pro-migrant NGOs are also criticized for the absence of migrants in leadership positions and their reticence to collaborate with the burgeoning sector of migrant led groups (Feldman 2007, 2008; Spencer 2005). Both NGOs claim some successes in influencing policy initiatives and practices around the employment rights of migrants and, to a lesser extent, family reunification and appeals to deportation.

This article details the origins of the two most prominent Irish pro-migrant NGOs, their relations to the state, their mobilization for migrants rights nationally and transnationally, and their efforts to collaborate with migrants. Based on an analysis of the annual reports, policy positions, and interviews with NGO directors, ${ }^{4}$ I argue that NGOs advocating for migrants in Ireland face a challenging political context for mobilization. Migrant rights remain an issue which is highly politicized, where Irish policy makers lack experience and expertise and where public opinion is at best ambivalent. ${ }^{5}$ The political context is also shaped by the Irish state's commitment to a neo-liberal approach to immigration and a tradition whereby the NGO sector is harnessed to the state through service provision and a reliance on state and foundation funding. These factors combine to narrow the repertoire of action available for pro-migrant NGOs to that of conventional lobbying and a focus on the least contentious policy targets such as labor market rights for documented migrant workers. While these constraints have worked to narrow NGO strategies they have also inhibited their capacity to construct partnerships with grassroots migrant-led organizations viewed by pro-migrant NGOs as competitors for scarce resources. Although reticent to build comprehensive relations with migrant-led groups pro-migrant NGOs use evidence based analysis to privilege the testimony of migrants in their policy advocacy and employ community development and leadership training to support the organizing efforts of individual migrants.

\footnotetext{
4 This work draws in part on interviews conducted with the directors of four national level NGOs working on immigrant, refugee, asylum rights, and anti-poverty and gender equality issues. I would like to thank the directors of these NGOs which include the Migrants Rights Centre of Ireland, the Immigrant Council of Ireland, the Irish Refugee Council, the Irish Anti-Poverty Network, and the National Women's Council of Ireland for their contributions to this research.

5 This work focuses predominantly on the migrant experience with reference to the situation of asylum seekers and refugees. Labor migrants, those seeking asylum, and refugees although occupying distinct legal positions in Irish society have been homogenized in public and political discourse into one derogatory category of "non-national." State policies and NGO advocacy for labor migrants is profoundly shaped by this conflation. Despite the obvious distinctions between migrants who enter the state for employment and those seeking asylum, they do share experiences of racism, discrimination, and social exclusion in Irish society (see Loyal 2007).
} 
In this work I first detail the Irish state's response to a rapid increase in the number of immigrants arriving on Irish soil. In particular I examine the policies and provisions available for economic migrants, asylum seekers, and refugees. Next, I review evidence of the state's failure to include and provide for its newest arrivals which I suggest by default devolves to individual migrants and their NGO advocates. Second, I explore how the broader political, social, and cultural context shapes the state's treatment of migrants, refugees, and asylum seekers and consequently the mobilization strategies employed by pro-migrant NGOs. Third, I assess the development of the pro-migrant NGO sector and their role in service provision and advocacy. I argue that these organizations have deployed a three pronged strategy in negotiating a contentious and highly constrained policy arena. Namely, NGOs have worked to create access points within formal political contexts and to contest negative framings of immigration within media and political discourse. They have also deployed multi-level strategies, mobilizing through transnational NGO coalitions working around intergovernmental organizations on the rights of migrants, refugees, and asylum seekers. Finally, I discuss the successes and failures of pro-migrant NGOs in advocating for and empowering their constituents. I suggest that a coalition of migrant-led, pro-migrant, and host society NGOs committed to an anti-racist and rights based approach to immigration and integration may provide a mechanism for the genuine participation of migrants in governance on immigration in Ireland. However, such collaboration will require what Feldman (2007, pp. 208-209) has termed as the acquisition of "intercultural capital" involving mutual learning between migrant activists and majority activists and importantly policy makers. I conclude that obstacles to such coalition based mobilization remain and include a circumscribed political context on immigration issues, a reticence among majority led NGOs to collaborate with the emergent migrant led NGO sector, and a competitive funding environment which renders collaboration difficult.

\section{Social Movement Theory and NGOs}

Social movement theory has been used to understand NGO's impact on institutions, their potential for agency, and their role as the carriers of new norms and ideas (McAdam 1996; Imig and Tarrow 2001; Joachim 2007; Joachim and Locher 2008). Specifically, political opportunity structure (POS), a concept employed by political process theorists, assesses how external structural factors influence the choice of NGO strategies and their possibilities to impact their environment. How open or closed a POS is to challengers is explained by reference to a series of interactive factors including the configuration of political institutions, cultural models, cleavage structures, and the broader international context. These "structural" factors inform the configuration of political actors characterized in terms of an alliance and or conflict structure which in turn interacts with an interaction context where the strategies of public authorities/policy makers interact in patterns of facilitation and/ or repression of the strategies of NGO actors. This is particularly useful in considering organizations involved in both service provision and advocacy that 
navigate the constraints and opportunities of state funding and state sponsored consultative fora while seeking to avoid co-optation and remain accountable to their constituents. $^{6}$

Political process theory (McAdam 1996; Kreisi 2004) applied specifically to migrant advocacy (Koopmans and Statham 1999; Statham and Koopman 2003; Guigni and Passy 2004) identifies how citizenship regimes and state policy towards immigrants, asylum seekers, and refugees profoundly shape the institutional and discursive opportunities and constraints facing actors mobilizing for migrants' rights. Challengers facing the structural constraints of a high profile policy domain such as immigration may seek to employ a diverse range of strategic alliances across national and transnational political contexts. Where few discursive opportunities and limited access to political elites are combined then demands by non-state actors for migrant's rights are easily ignored (Statham and Geedes 2006). ${ }^{7}$ The Irish immigration regime is ring-fenced within the government ministry of Justice Equality and Law Reform (DJELR), which has a poor tradition of consultation with NGO actors. The Irish media have created some discursive opportunities for debate on immigration, although NGOs are far outweighed by racialized public and political discourse on migrants and asylum seekers. Pro-migrant NGOs mobilize in this constrained context where, as Feldman argues, "immigration is but one dimension of the many current dynamics and dilemmas of national development and globalization in Ireland where migrants and immigration have become the foils for the projections of uncertainties and conflicts that have little connection to them" (2008, p. 2). As a result, as Fanning argues, "Integration policies remain limited, migrants and other ethnic and racial minorities remain marginal within Irish society, and their NGO advocates are often also marginal in policy debates" (Fanning 2007b, p. 15).

Pro-migrant NGOs have developed a strategic repertoire aimed at influencing institutional and discursive opportunity structures. First they have created their own alliance structure composed of non-state actors newly receptive to the diversification of their constituents and eager to gain credibility with and expertise about the growing numbers of ethnic and racial minorities within migrant communities. These organizations include antipoverty, women's rights NGOs, and Trade Unions. ${ }^{8}$ Promigrant NGOs have also worked to patch together a series of allies throughout

\footnotetext{
6 This research also speaks to issues social movement scholars have raised regarding the advantages and disadvantages of looking beyond beneficiary constituents for membership, support, and resources as well as the need for elite conscience constituents and adherents and the resources they can provide when working for constituents who face resource constraints and whom may occupy a precarious legal status (Edwards and McCarthy 2004).

7 Koopmans and Statham (1999) argue that the existence of comprehensive equality and antidiscrimination agencies and legislation is also an important factor in shaping the context for groups mobilizing on migrant rights.

8 Other organizations regionally and nationally based working with immigrant, refugee, and asylum seekers populations include AkiDwA, Cairde, Children's Rights Alliance, Doras Luimni, Free Legal Advice Centres, Galway Refugee Support Group, Integrate Mallow (Avondhu Development Group), Integrating Ireland, Integration of African Children in Ireland, Irish Council for Civil Liberties, Irish Refugee Council, Longford Women's Link, Louth African Women's Group, Mayo Intercultural Action, NASC, New Ross Intercultural Group and Direct Provision Integration Group, Refugee Information Service Refugee Project, Tallaght Intercultural Action, Vincentian Refugee Centre, Waterford Refugee and Asylum Seeker Council, Irish Immigrant Support Centre.
} 
different state bodies made up of public officials sympathetic to the goals of these organizations and dependent on NGOs for information and service provision. This later form of engagement has enabled pro-migrant NGOs to push for concessions and a reconsideration of rulings on cases for individual migrants and their families and has resulted in some strengthening of labor market protections for migrant workers.

Second, pro-migrant NGOs have resorted to international political contexts including the European Union (EU) and the United Nations (UN) as arenas for mobilization on the rights of migrants in Ireland. Working through transnational NGO coalitions, including the European Platform for Migrant Workers Rights, the European Network Against Racism, and the Platform for International Cooperation on Undocumented Migrants, these organizations have pushed for the Irish state to ratify international conventions on human trafficking, protections for undocumented migrants, and rights to family reunification. However, EU policies are weak with narrow directives on family reunification and long term resident rights, and these have been ignored by the Irish state (European Commission 2006). In effect, Ireland has a long tradition of opting out of binding forms of international law and policy on matters of immigration and most recently the rights of migrants (while opting in on border control initiatives). ${ }^{9}$ The UN has proved a more useful context for employing "shaming" tactics regarding the Irish state's record of non-compliance with international accords. Most recently the UNHCR recommended a substantial revision of the Irish government's proposed Immigration, Residence and Protection Bill 2008 (UNHCR 2008). International contexts have also been the site for litigation strategies, pro-migrant NGOs have supported cases including a July 2008 European Court of Justice ruling which overturned Irish restrictions on the residency rights of non-EU citizen spouses (O'Brien 2008). However, neither international forum has to date proved decisive in pressuring the Irish state to shift from its defensive posture regarding immigrants, asylum seekers, and refugees to embracing international rights-based approaches. ${ }^{10}$

Third, pro-migrant NGOs have engaged the discursive opportunity structure, in particular advancing a reframing of the racialized discourse employed by the state and media in their treatment of immigration. Analysis has suggested that the Irish state and its agents have invested in discursively reproducing essentialized versions of Irishness through the erasure of Irish experiences of emigration and the deployment of a form of selective memory and nationalism aimed at drawing a boundary between Irish citizens and certain immigrants (Crowley et al. 2006, pp. 4-5; Lentin 2007). Using the testimony of individual migrants in newspaper, radio, and documentary formats, both the ICI and the MRCI have challenged the

\footnotetext{
9 Menz (2008) has suggested that the Irish state cherry picks the EU policies it wishes to take part in including policy on carrier sanctions, biometric data, and the retention and storage of passenger data. Alleged European pressure is then rhetorically constructed to justify the implementation of certain policy tools aimed at securitization of borders and the surveillance of migrants, asylum seekers, and refugees.

${ }^{10}$ EU policy on immigration passed by the European Parliament on June 18, 2008 makes it possible to detain irregular migrants for up to 18 months. The rules, or "return directive" will not cover asylumseekers, but all those who overstay their visa period will be affected. The policy has been roundly criticized by the United Nations and Amnesty International.
} 
predominant construct of immigrants as suspect, untrustworthy free loaders who displace Irish workers with accounts of migrants as ordinary people with dependents who often experience isolation, discrimination, and the vulnerabilities associated with uncertain legal status.

\section{Ireland: From Emigration to Immigration}

Until the global economic recession of late 2007, Ireland had experienced 10 years of unprecedented economic growth and was hailed as the success story of EU membership and neo-liberal economic policy making (Anderson and O'Brien 2006). Characterized as the "Celtic Tiger," Ireland was heralded as a highly globalized nation, with low levels of unemployment, declining rates of poverty, and a vibrant cosmopolitan and inclusive population. Social scientists have in turn deconstructed this "hagiography" of the Celtic Tiger, defining it as a superficial and unsatisfactory narrative which ignored the complex dialectics of social change and the growing levels of inequality which accompanied these social and economic shifts (Kirby et al. 2002; Coulter and Coleman 2003; Bartley and Kitchin 2007; Fahey et al. 2007; Mac Éinrí 2007b). Notably, twenty percent of the Irish population remains at risk of poverty, one of the highest rates in the EU (Central Statistics Office 2006, p. 14). The global economic recession has had significant implications for Ireland, including the collapse of its construction industry and a projected unemployment rate in excess of $10 \%$ for 2009, the highest in 10 years (White 2008, p. 3). After successive years of budget surplus, the Irish state also posted a budget deficit of $€ 7.9$ billion in the first 11 months of 2008 , compared to a $€ 1.6$ billion surplus a year earlier (Slattery 2008).

The 1990s had also marked the beginning of a period where unemployment and emigration were replaced by relatively low levels of joblessness, significant return migration, and substantial immigration from non-EU countries. Census data suggest that more than one in ten people now living in Ireland are non-citizens (Central Statistics Office 2006). Official estimates, however, may not accurately reflect the exact proportion of the population who are foreign nationals, with some commentators suggesting that irregular workers and family reunification has pushed the figure nearer to $15 \%$ of the population now of non-Irish descent (Loyal 2007). While Ireland is not unique in Europe regarding the proportion of the population now of foreign heritage, what is significant in the Irish case is the rapid time frame of less than 10 years within which these shifts occurred. ${ }^{11}$ Research suggests that most migrants are young, well educated, and concentrated in the service industries and agriculture (NESC 2006).

\footnotetext{
11 Analysis of the 2006 census, which for the first time included questions on racial and ethnic status, suggests that the number of non-Irish nationals in Ireland increased from 222,000 in 2002 (equivalent to $5.8 \%$ of the population) to around 400,000 in 2006 (about 9.4\%). Migrants from Poland, Latvia, Lithuania, Romania, and the Philippines make up the largest numbers of economic migrants currently resident in Ireland. Nigerians and Chinese nationals are the largest populations resident from outside of Europe (Central Statistics Office 2006).
} 


\section{The Irish State: Immigrants, Asylum Seekers, and Refugees}

\section{The Citizenship Amendment of 2004}

In legal terms, the Irish state has responded decisively to the issue of immigration. A constitutional amendment passed in June 2004 removed the automatic right of citizenship for children born on Irish soil. ${ }^{12}$ Pro-migrant NGOs, including those discussed here, campaigned vigorously against the referendum. However, they proved no match for the government's campaign which rested on a racialized discourse that suggested Ireland was in danger of becoming a haven for exploitative "non-nationals" and that Irish exceptionalism with regard to its citizenship eligibility had to be remedied so as to conform to EU standards (Beesley 2004).

A crucial distinction institutionalized in the 2004 referendum was one between "nationals" and "non-nationals." The "national-non-national" dualism codified immigration in terms of longstanding debates about belonging within Irish society. Here it drew on a history of exclusionary nationalism that equated Irishness with ethnic homogeneity (Brandi 2007; Fanning 2007b; Fanning and Mutwarasibo 2007, p. 439). Lentin and McVeigh suggest that the referendum was indeed a landmark event in the ongoing transformation of Ireland from a racial state to a racist state, in which citizens are differentiated from non-citizens (Lentin and McVeigh 2006a b, p. 55). Legislation to implement the constitutional change was introduced at the end of 2004 when the government suspended the residence claims made on the basis of children born in Ireland.

\section{Policies and Provisions for Asylum Seekers and Refugees}

Unlike most European countries where labor migration preceded the arrival of asylum seekers, early debates on immigration in Ireland focused on those seeking asylum and refugees (Loyal 2007, p. 37). Menz's (2008) and Boucher's (2008) analyses of immigration politics in Ireland and work by Statham (2003) on antiasylum rhetoric in Britain confirms the role of political entrepreneurs in conflating immigration and asylum to trigger normative debates about the cultural basis of membership and to perpetuate the persistent though inaccurate stereotype that asylum seekers engage in welfare fraud and are security threats. Statham (2003, p. 173) suggests that anti-immigrant and anti-asylum discourse comes directly from political elites and has purchase in the general public not purely as an expression of anti-asylum seeker sentiment but rather as a way to express grievances and disillusion about other social issues. Loyal (2007) argues in the Irish case that asylum seekers serve as scapegoats for the social problems which accompanied the Celtic Tiger phenomenon now exacerbated by the recent economic downturn. Civil society actors are then tasked with mobilizing against this expressed position which in turn creates a formidable obstacle to effective lobbying. An overview of the

\footnotetext{
12 Ireland had until a constitutional amendment in 2004 a distinctive approach to the issue of citizenship offering citizenship at birth to all children born in the state while, at the same time, making an Irish passport available to the grandchild of any Irish citizen, born anywhere in the world to parents of any combination of nationalities.
} 
policies towards and experiences of asylum seekers and refugees is important then in making sense of the political, social, and cultural landscape for activism on migrant's rights.

Under current legislation asylum seekers are denied access to work and higher education. They do receive a minimal state welfare benefit which isolates them from the indigenous population and has fostered the perception among some sectors of the Irish population that they are "free-loaders" on the Irish state (Bacik 2004 , p. 188). Ireland has a poor record for granting asylum and refugee status. A significant rise in applications between 1992 with 39 applicants to 11,600 in 2002, led to what Mac Éinrí (2007, p. 239) terms as a series of moral panics in media and political discourse. Applicant numbers have fallen significantly, to 4,242 in 2006 and 2,936 by the end of September for the year 2007 (Office of Refugee Applications Commission 2007). Out of a total of 48,000 asylum applications between 2000 and 2005, only 6,087 were recognized as refugees (Irish Refugee Council 2007). ${ }^{13}$

\section{Policies and Provisions for Economic Migrants}

The Irish response to immigration must be understood as shaped in part by the Irish political and economic elite's investment in a neo-liberal response to globalization. This policy paradigm is informed by the application of free market policy solutions to social problems and the perception that migrants are solely economic actors (Allen 2007; Fanning 2007a, pp. 245-249). From this perspective migrants are understood to be "guest-workers" best served by employer driven annual nontransferable work permits with no provisions for family reunification or permanent residence (Allen 2007, pp. 85-86). Between 1999 and 2003 the number of work permits provided increased by $700 \%$ (Ruhs 2005, p. 13).

The worker permit system has to date been poorly regulated by an underresourced and understaffed agency charged with monitoring employer practice, the Labour Inspectorate. This has in turn created conditions for migrant worker exploitation. In this regard, migrant women are especially vulnerable. Migration in the Irish context is highly feminized and is part of broader trends acknowledged in the globalization of women's work in caring, cleaning, and prostitution (Conroy 2003; Ehrenreich and Hochschild 2003; Pillinger 2006). An Employment Permits Act introduced in 2006 created some protections for migrant workers but formalized a dual system of fast tracked work authorizations/visas available to professionals in information and computing technologies and medical health alongside regular work permits available to "less" skilled occupational categories. Placed alongside the restrictions accompanying work permits, these different tracks to employment in Ireland reaffirm the stratifications within the dual labor market. Under this twin track approach highly skilled workers are selected as potential citizens whereas temporary workers remain sponsored by employers (Mac Éinrí 2007a). Work permit

\footnotetext{
13 The 2007 annual report from the Office of the Refugee Applications Commissioner states that 3,900 people applied for refugee status in Ireland, representing the lowest number of applications since 1997. The top six applicant countries were Nigeria, Iraq, China, Pakistan, Georgia, and Sudan.
} 
holders earned up to $14 \%$ less than indigenous workers in similar jobs, despite their relatively higher levels of education (Quinn and Hughes 2004, p. 1). Feldman (2008, pp. 3-4) cites recent ethnographic work with various migrant communities to suggest that these differential immigration statuses do in turn create different levels of opportunity and possibilities for migrants to create the forms of social and cultural capital they require to succeed economically and socially in the "new" Ireland. She also suggests that aside from its stratifying implications for immigrants, immigration policy also contributes to the public perception that immigrants are outsiders and undeserving of the state's resources and accommodation.

Migrants seeking information and government services in Ireland often encounter significant time delays and at times incorrect or incongruous information from state agencies tasked with adjudicating employment, residency, and social service issues (NESC 2006; Feldman 2008). ${ }^{14}$ In addition, translation services are non-existent, particularly in the areas of health and justice (Phelan 2006). One result of the poor performance of public bodies in serving ethnic minority/migrant communities has been an over reliance on majority led NGO's to intervene and mediate on their behalf (National Economic and Social Forum 2007; NCCRI 2007). Service provision around the immigration system is accordingly largely devolved to NGOs. However the resources to support such provision remain insignificant (Boucher 2007).

EU citizens and non-EU nationals who have migrated to or seek asylum in Ireland face considerable challenges in their efforts to integrate into Irish society (Hughes et al. 2007; Mac Éinrí 2007b). The Migrant Integration Policy Index for 2007, a comparative tool for assessing the integration of migrants in European countries, gave Ireland's long-term residence policies the worst score of all 28 countries surveyed. The Index also rates migrants' rights to family reunion in Ireland as highly discretionary. The implications for migrants, asylum seekers, and refugees in Ireland is that their rights to work, sponsor family members, access benefits, and live in Ireland for long periods are still subordinated to their work status (Niessen et al. 2007, pp. 106-111). A 2006 survey of migrants and their experiences of racism confirmed that Ireland shares patterns of racial discrimination in work and in the public domain evident in most European countries (McGinnity et al. 2006). ${ }^{15}$ A March 2006 Amnesty International report found that the Irish Government had failed to acknowledge the existence of racial discrimination in its laws, policies, and institutional practices, and to take meaningful steps to combat it (Beirne and Jaichand 2006). A National Action Plan Against Racism (NPAR) launched in 2004, alongside the National Consultative Committee on Racism and Interculturalism (NCCRI) and the Equality Authority, an independent body set up in

\footnotetext{
${ }^{14}$ Examples of discretionary and inconsistent practice include the practice of the DJELR of issuing stamps normally given to international students to child dependents of non-EU workers. This has led to problems for dependent children when applying for long term residency, accessing third level education and the labour market (ICI 2007a).

15 Data collected by the Central Statistics Office of Ireland also suggest that a significant proportion of ethnic minorities experience racial discrimination and social exclusion but that only a small number have taken any action and that almost half have no understanding of their rights under Irish equality legislation (Central Statistics Office of Ireland 2004, pp.1-3).
} 
1998 is tasked with enforcing equality legislation have provided important points of reference for NGOs in their efforts to address migrant rights. ${ }^{16}$ However, they are weakened by their relative lack of resources and their narrow remit. Notably, in December 2008 citing budgetary concerns related to the economic downturn, the Irish government abolished the NCCRI and cut the Equality Authority's budget by $43 \%$ resulting in the resignation of its director and the eradication of its core support functions.

\section{The Political Opportunity Context for Pro-Migrant NGO Mobilization}

\section{Politics and Public Administration}

Although the low level of electoral support for far-right or anti-immigrant platforms is a positive feature of Irish politics, political institutions remain largely monocultural. $^{17}$ The central target for pro-migrant NGO mobilization include the Department of Justice, Equality and Law Reform (DJELR) which holds main responsibility on immigration, asylum, and citizenship and the police force unit Garda National Immigration Bureau (GNIB) responsible for enacting legislation. ${ }^{18}$ The second government department relevant for pro-migrant organizations is the Department of Enterprise, Trade and Employment (DETE) which deals with labor migration policy, the administration of work permits and funds for skills training.

Any assessment of the Irish political context for NGO mobilization on migrant issues must take into account the discretionary power of the permanent civil service and the silo mentality of government ministries working on immigration and integration issues. A junior cabinet post for integration established in June 2007 is tasked with the provision of language classes for legal resident labor migrants and has no jurisdiction over immigration issues. ${ }^{19}$

Government ministers are supported in their work by the "permanent government," the civil servants who staff government departments. Senior civil servants have considerable scope to influence policy and are often the main interlocutors for NGOs rather than specific Ministers (Spencer 2005, pp. 22-24). Menz's (2008) work on managed migration in European countries suggests that in the Irish case NGOs' attempts at influencing immigration legislation have been largely frustrated by senior government officials who are unwilling to concede to the establishment of regularized access channels for NGO input.

\footnotetext{
16 This agency enforces the Employment Equality Act 1998 and the Equal Status Act 2000 which outlaw discrimination in employment, vocational training, advertising, collective agreements, the provision of goods and services, and other opportunities to which the public generally have access.

17 Ireland is distinctive in allowing non-citizens legally resident for 6 months or longer to vote in local elections. However, political parties, according to a series of studies, do not see the value of ethnic minorities as constituents or candidates and the formal right to vote at the local level has not provided any significant access to political power at state level (see Chadamoyo et al. 2007, p. 451).

18 The DJELR is also formally responsible for antiracism and equality legislation.

19 Immigration and integration policies are deemed by the state as separate spheres of policy competence.
} 
Social Partnership, NGOs, and the Politics of Immigration

Political process theorists argue that social movement organizations (SMOs) working on a "high profile domain" issue such as immigration are uniquely constrained when engaging with established power relations within a polity. As discussed above, the polity is best understood as a matrix of political, cultural, and symbolic elements which configure in patterns of facilitation and repression or opportunity and constraint. The concept of prevailing strategies is instructive here in suggesting an identifiable set of procedures typically employed by members of the political system when dealing with challengers (Kreisi 2004, p. 71). Such strategies can be exclusive, marked by repression, confrontation, and polarization, or integrative, characterized by forms of facilitation, cooperation, and assimilation.

The model employed by the Irish state since the late 1980s to manage its relations with civil society organizations can be characterized broadly as integrative. Under what has been termed social partnership community and voluntary sector organizations have since 1987 had a role in negotiating multi-annual state "development" plans. Under this arrangement civil society organizations are invited by the state to consult in periodic public policy and wage agreements. The management of economic migration and measures such as language training to facilitate the integration of legal migrants are the predominant immigrant related policy areas included in social partnership negotiations (Fanning 2007c, d).

Social partnership has been characterized as a form of "competitive corporatism" and while credited with a key role in Ireland's recent economic success it has also been suggested that the structures of social partnership exert a strong pressure against dissent. Social partnership has also marked a distinct trajectory for the Irish NGO sector, in particular community development groups, many of whom advanced radical agendas in the 1970 s but by the 1980 s had entered into agreements to provide services to the state in exchange for access to funding opportunities and participation in episodic corporatist policy deliberations. ${ }^{20}$ This it has been argued resulted in a professionalization, bureaucratization, and deradicalization of the sector, whose activities have increasingly fallen under the scrutiny of public officials and who, through a myriad of local and national structures, has been drawn into complex exchange relations with the state (Geoghegan and Powell 2006; Meade 2005; Murphy 2002; Daly 2008). Promigrant NGOs operate within this context where NGOs negotiate webs of partnership agreements with local and national statutory bodies. Working outside of these arrangements can exclude an organization from crucial funding opportunities and access to political operatives. The national women's rights organization (NWCI) experience of social partnership provides an example of the power of the state to offer its certification and also decertification to NGOs. The NWCI, unhappy with the government's 2004 national development plan, "negotiated" through the

\footnotetext{
${ }^{20}$ National Social Partnership is a formal arrangement in which each government's policy program is negotiated and progress monitored by a committee of representatives drawn from four pillars: business, trade unions, farming, and the community and voluntary sector. NGOs participate in the negotiations as part of the Community and Voluntary sector pillar and in signing the agreement are eligible to become members of the monitoring committees.
} 
mechanisms of social partnership, refused to sign off on the policy agreement. The state in turn punished this NGO by excluding it from the next series of policy negotiations and subsequently ignored its input into the development of a long awaited national women's strategy (Cullen 2008). For pro-migrant NGOs the political contention surrounding immigration coupled with a lack of public support for a rights based approach on immigration and asylum matters makes a system of "partnership" which provides a form of conditional consultation to NGO interests particularly problematic.

Boucher (2008, pp. 4-9) argues that the state uses a form of "social partnership lite" on immigration related issues which allows it to solicit yet disregard promigrant interest input. The official involvement of pro-migrant NGOs in social partnership committees has he argues allowed the state to claim a commitment to an interculturalist stakeholder approach on immigration. Social partnership lite also allows the state to advance a schizophrenic discourse where the benefits of immigration and integration are proclaimed while responsibility for the integration of immigrants is devolved to individuals and immigration policy remains framed as a security and border control issue.

\section{Irish Pro-Migrant NGOs: Advocacy and Service Provision}

While NGOs including Amnesty International, the Irish Council of Civil Liberties, and Comlamh (an organization of returning overseas development workers) have a tradition of advocating for the rights of asylum seekers and refugees in Ireland, the Irish Refugee Council, established in 1992, was the first national organization specifically devoted to the needs of non-citizens arriving on Irish soil. ${ }^{21}$ The more recent growth of organizations dates from the early twenty-first century. ${ }^{22}$ The Immigrant Council of Ireland (ICI) and the Migrant Rights Centre of Ireland (MRCI), both established in 2001, are the largest NGOs in the sector. The ICI and the MRCI were established as parallel organizations, a result in part of the suggestion from a foundation-the Atlantic Philanthropies. ${ }^{23}$ The mission of the Migrants Rights Centre of Ireland is stated as "promoting the conditions for the social and economic inclusion of migrant workers and their families who are in situations of vulnerability" (MRCI 2007a, p. 6). The director of the ICI describes the organization as primarily a service provider to the immigrant population "in order to help individuals navigate the immigration and asylum system" (interview

\footnotetext{
21 Most activists have had overseas development work experience in Africa and/or Central America.

22 Two umbrella organizations are also noteworthy. The Coalition Against the Deportation of Irish Born Children (CADIC) is a diverse range of mostly majority-led organizations that were successful in getting the government to step back from mass deportations of children and their families after the constitutional amendment. Cairde is also an umbrella organization which advocates for support to address health inequities among ethnic minorities.

23 In some sense there exists a division of labor between the two organizations which stems from the original funders of both organizations-Atlantic Philanthropies and a US exchange organized by the Migration policy group in Washington D.C. which helped inform activists involved in setting up both organizations.
} 
with the director of the ICI, July 31,2007$).{ }^{24}$ The main distinction drawn between these two organizations rests on the MRCI's focus on labor issues while the ICI is concerned primarily with the immigration system. In reality both organizations overlap somewhat in their areas of expertise and the services they provide.

Both NGOs utilize a range of conventional tactics to engage the institutional and discursive opportunity context. These include private and public correspondence with public officials, press releases, parliamentary lobbying, litigation, and strategic alliances with other NGOs, with nonprofit labor recruitment agencies, citizen advice centers, community development organizations, and trade unions. Both organizations have in addition cultivated working relations with state bodies including the police force and the Labour Inspectorate. International strategies are also employed through organizational membership of international migrants rights and anti-racism NGOs. The NGOs reviewed here receive a small yet crucial amount of state project funding. However, the majority of their financial support to date comes from private religious and philanthropic foundations (MRCI 2007a, p. 24). ${ }^{25}$ Since November 2007 funding for organizations working on these issues has been centralized to one government department of Community and Rural Affairs. This move also marked the amalgamation of funds into fewer available lines of support increasing resource competition between organizations (Pobal 2007).

A central issue for the MRCI is irregular migration and in particular labor migrants and their families. In 2006 the organization responded to 4,000 queries on issues including family reunion, work permits, work place exploitation, and residency issues. The majority of migrants contacting the organization required advocacy rather than merely information. While this NGO is based in Dublin city, it claims to build the capacity of local groups to support migrants and has a stated aim of "the translation of individual experiences into collective actions" (MRCI 2007a, p. 6). ${ }^{26}$ The MRCI acting director characterizes their approach as "evidence" based in employing quantitative and qualitative data collection through a computer program to track their case management system. This NGO then packages these data for the consumption of policy makers and politicians. Indeed, the paucity of data on trends and patterns of the migrant experience in Ireland have provided the organization with an opportunity to gain access and credibility with policy makers and politicians by providing "a strategic combination of statistics and migrant testimony" (interview with the acting director of MRCI, June 21, 2007).

While the ICI has working methods that are similar to the MRCI, it has invested in litigation as a strategy through its independent law center and is the only NGO in

\footnotetext{
24 The ICI dealt with 10,000 inquiries in 2007 from its information service a rise of $33 \%$ over the number of requests in 2006. The organization receives no state funding for its core services relying on a subvention from Citizen's Advice Bureaus for its hotline.

25 The MRCI Annual Report lists it financial sources as 6\% state; $9 \%$ semi-state; $68 \%$ philanthropic foundations; $14 \%$ other non-state; $3 \%$ fundraising events, donations, and income generation (MRCI 2007a, p. 24).

26 The MRCI assists individuals through negotiation with employers, making representations to employment complaints bodies and the Labour Inspectorate. The organization also aids undocumented workers in regularizing their situation by negotiation directly with the Work Permit Section of the DJELR.
} 
the immigration sector with this facility. This NGO is also research driven, commissioning a variety of reports on topics including labor migration; family reunification; trafficking; the feminization of migration; and comparative studies on different models of international best practice in the area of immigration and integration (ICI 2003, 2004, 2007b).

\section{Alliance Structure: State Bodies}

Despite receiving little state funding, the ICI and the MRCI play an important role in addressing the service deficit of state bodies working on immigration issues. The police force GNIB relies on both NGOs to inform it of incidents where they suspect migrants are being trafficked for work purposes. The Labour Inspectorate, replaced in 2008 by the National Employment Rights Agency, has also benefited from the documentation and testimony that these NGOs collect from migrants who have been exploited by an employer. Together these NGOs fill an essential gap in available service provision for the immigrant population in Ireland. In some ways, both organizations facilitate the functioning of a variety of state and semi-state bodies working on immigration issues. The MRCI director suggested that in the absence of services provided by her organization "the DETE work permit section would cease to function" (interview with the acting director of MRCI, June 21, 2007). An Education and Training Department run by the ICI also provides courses on migrants' rights and entitlements for a range of statutory groups throughout Ireland. This reliance on NGOs to carry out functions of state bodies has been characterized by Grey in her analysis of Irish immigration and integration policy as "governance at a distance" (Grey 2006, p. 20). These relationships also fit with the state's general neoliberal, third way approach to public sector services which has involved a mix of privatization and a reliance on third sector or NGO service provision.

The DETE with its connection to labor issues is according to the MRCI the most open of all government departments, while the DJELR remains the least receptive to NGO input. In similar terms to the MRCI the ICI director noted that despite receiving on occasion referrals from the department's lower level officials for help, a relationship that had taken years to craft, senior civil servants in the DJELR continued to place considerable roadblocks to NGO lobbying efforts (interview with the director of the ICI, July 12, 2007). This confirms previous research which suggests that senior civil servant policy makers on the whole perceive NGOs in the immigration area as properly concerned with humanitarian relief but unrepresentative and unqualified to offer input into policy deliberations (Spencer 2006). Senior civil servants who do not value NGO input can cut off access for organizations trying to influence a policy trajectory particularly when coupled with a government minister sharing similar preferences.

\section{Alliance Structures: Non-State Actors}

While both NGOs are considered the main interlocutors on migrant issues by state bodies and clearly fulfill a service deficit for their constituents, the MRCI and the ICI are not included as formal partners in social partnership. They rely instead on 
their membership in an alliance of NGOs, the Community Platform, who participate in these public policy negotiations. Their input then is through this broader coalition and indirectly through the national women's rights organization, the National Women's Council of Ireland (NWCI) and trade unions. Notably, both the ICI and MRCI differ in their level of enthusiasm for participation in NGO alliances and the social partnership process. The ICI drew attention to the critique of social partnership as "partnership with no power" and underlined the fatigue and frustration that many NGOs experienced as a result of their investment in these forms of cooperation with the state when the outcomes were less than desirable (interview with director of the ICI, July 12, 2007). On other hand, the director of the MRCI had recently been voted onto a monitoring committee for the labor market commitments made in the partnership agreement and professed a more positive assessment of collaboration with other NGO actors through the social partnership process (interview with the acting director of MRCI, June 21, 2007). Despite their acknowledgment of the inherent limits to social partnership, both directors agreed that participation in the NGO representation has provided opportunities to construct alliances with other parties including trade unions.

The Irish Congress of Trade Unions (ICTU), the central organization for union membership, while slow to explicitly advocate for migrant rights has now become an important ally for pro-migrant NGOs mobilization. One factor which has encouraged the ICTU to ally with pro-migrant groups has been the weakening of workers' rights and the increase in agency based or atypical employment in nonunionized contexts seen as a driver of Celtic Tiger economic growth. Two highly publicized cases of work place exploitation, one a Turkish construction company hired by the state to complete road construction and the Irish Ferries company underpayment of foreign born workers, galvanized ICTU support of migrant labor market rights. The ICTU has developed materials aimed at recruiting documented migrant workers and joined with pro-migrant NGOs in its critique of the proposed Immigration, Residence and Protection Bill 2008 (ICTU 2008). The MRCI domestic workers group campaign for a code of conduct for employers marked the first concerted work with trade unions and resulted in a commitment from the government to develop a voluntary code of practice for employers of domestic workers. A core group of seven migrant women spearheaded these negotiations and continue to campaign for a more formal agreement and monitoring mechanisms in the form of a Joint Labor Committee. Despite the nonbinding nature of the code, the acting director stated that the value in this campaign was two-fold: it further engaged trade unions on the issue of migrant worker exploitation and it also highlighted "what goes on in a very invisible sector in Ireland" (interview with the acting director of MRCI, June 21, 2007). ${ }^{27}$ NGOs have recorded substantial evidence that many migrants are receiving wages below the minimum wage level and have documented several incidents of migrants being forced to work hours 1214 a day, 7 days per week without any holidays. Those most vulnerable are migrant women employed as domestic workers. (MRCI 2004b, 2007a, 2008).

\footnotetext{
27 The MRCI is simultaneously pursuing a legal case regarding the powers of the Labour Inspectorate to enter into and investigate the private home.
} 
The 2006 10-year social partnership agreement entitled "Towards 2016," contains provisions aimed at the labor market exploitation of migrants, lobbied for specifically by the ICTU in alliance with the ICI and MRCI (MRCI 2007b). Amongst these is the establishment of the National Employment Rights Authority, an increase in the number of Labor Inspectors and legislation defining the exploitation and abuse of workers as a criminal offence (Department of Taoiseach 2006). NGOs and trade unionists have welcomed these commitments but remain skeptical regarding the resources to be made available for their implementation (Begg 2007). ${ }^{28}$

Social partnership has then provided pro-migrant NGOs a site to construct strategic coalitions and to exert influence on parties like trade unions that possess in relative terms stronger voices in this policy making forum. However, the fact that neither of the pro-migrant NGOs is included as stand-alone social partners suggests that immigration issues remain too politically contentious for the state to include them in this form of negotiation. The consequence of this for migrants in particular and asylum seekers and refugees more generally is that while they must rely in large part on majority led representation, this representation is in itself dependent on an additional level of mediation through more established non-state interests. In this sense migrants and other ethnic minorities are reliant on the capacity of the majority NGO sector and non-state bodies such as trade unions to be sensitized to migrant issues and to weight their demands with sufficient importance.

Feldman et al. (2005) describes a situation where NGOs working with established constituencies such as women, youth, and the disabled have had a poor record in including migrants in their decision making apparatus. However, some national organizations, including the NWCI have more recently embraced the involvement of ethnic minority women as a central goal (NWCI 2007; Cullen 2008). Both the ICI and MRCI attend NWCI events and have endorsed NWCI efforts to mobilize for migrant women's rights and to draw attention to the feminization of immigration. The Irish branch of the European Anti-Poverty Network, a central fixture within the Irish NGO landscape working on poverty issues, has also forged links with the ICI and the MRCI, publishing a fact sheet on the experience of poverty and the challenges to integration facing the "new communities" (EAPN Ireland 2007).

\section{Pro-Migrant NGOs and Migrant Led Organizations}

While both the MRCI and the ICI have established some degree of credibility with policy makers and state bodies working on labor issues, both directors acknowledged that their organizations struggled with creating durable and facilitative links with their migrant constituents. Notably, neither organization claims to have comprehensive or organic links with migrant led groups. When asked about the role of the MRCI in supporting the development of migrant led groups, the acting director outlined the existence of a leadership training program and migrant led

\footnotetext{
28 The final Employment Law Compliance Bill 2008, which was published on March 18, 2008, provides for the establishment of the National Employment Rights Authority (NERA) on a statutory footing with greater enforcement powers than its predecessor, the Labour Inspectorate. However, to date while undocumented employees have been deported, employers found to be exploiting these workers have not been subject to prosecution.
} 
occupational based issue groups. Leadership training seminars are offered to interested migrants who participate in a Migrants Forum which meets every 6 weeks. In addition, physical space, tool kits and information on policies and proposed legislation are provided to migrants involved in MRCI support groups for workers from agricultural, restaurant, and domestic sectors. The acting director suggested that support groups were organized specifically around occupational sectors for strategic reasons, namely that "work is defined as a unifying experience and can create the basis for solidarity across ethnic and social divisions" (interview with the acting director of MRCI, June 21, 2007).

The degree of initiative from migrants themselves in the occupational support groups is difficult to gauge, although the MRCI staff state that all of the groups are "migrant led." The agricultural support group has been a particular success devolving itself from the MRCI and becoming an independent migrant led organization-the Agricultural Workers Association. Certainly such initiatives suggest that majority led NGOs can play a role in creating mechanisms for the representation and participation of migrants in policy debates. However, the acting director acknowledged that the support groups are limited by the use of English as the predominant language (interview with the acting director of MRCI, June 21, 2007). It is also apparent that this NGO has a preference for working with migrant led groups which it has had a role in creating. Apart from connections to specific high profile migrant led organizations such as AKiwada, a national level African feminist NGO, the MRCI works predominantly with other majority led NGOs.

When asked to assess their relations in general with migrant led groups, the acting director of the MRCI acknowledged that the organization needs to do more outreach. However, this aspiration was qualified by the MRCI's concern regarding the representativeness of organizations claiming to represent migrants and ethnic minorities. Examples of organizations which were deemed suspect in this regard were the Romanian Society of Ireland and the Ireland India Club, groups who were seen to represent a small and somewhat elite sector of their communities' resident in Ireland. Migrant led groups are then from the MRCI's perspective not always a good bet for funding investments as "they might organize an event or two but do not have the capacity to provide services or advocate for their communities in the manner that larger groups such as the MRCI do" (interview with the acting director of MRCI, June 21, 2007). The acting director stated clearly that the MRCI does not claim to represent migrant workers. However, this NGO contends that "we relate the experience of migrant workers who use our services directly to policy makers" (ibid). Certainly competition for funding also plays a role in creating reticence within this NGO to building relations with the migrant led NGO sector. As the acting director stated "at the end of the day this is a survival issue, and the funding environment is competitive and does hinder collaboration" (ibid).

When asked about the exact nature of the ICI's links to migrant led groups, the director stated that rather than explicit links with migrant led organizations the "migrant voice comes through our services." The organization had worked through focus groups with various migrant constituents but had recently decided to shift away from this strategy. The reason for this shift rested on complaints from specific migrant interlocutors who had expressed fatigue with being consulted so frequently. 
As the director stated "When you hand pick a couple of migrants and bring them into a focus group I am not sure how effective it is" (director of the ICI, July 12, 2007). A consultation exercise on the provision of health services for ethnic minorities and the "new communities" facilitated by the ICI, resulted in few of the focus group recommendations being implemented and reflected poorly on the ICI.

In similar terms to the MRCI, the ICI director stated that the organization tended to work with well established organizations such as the Indian Council, the Chinese Professional Association, and the above mentioned feminist NGO AKiwada, particularly on the issue of gender violence. However, she also offered that in her experience many migrant led organizations were inexperienced and became quickly frustrated when they met resistance, particularly from state bodies when lobbying for policy change. She cited examples of the migrant led sectors lack of capacity evidenced by "organizations which prepared manifestos or budget submissions 6 months too late to feed into the political cycle" (director of the ICI, July 12, 2007). ${ }^{29}$

\section{Discursive Opportunity Context}

Researchers and NGOs have documented a growing anti-immigrant sentiment anchored in the racialisation of migrants by the state and the media and played out in a lack of distinction made by the public between ethnicity and nationality (Boucher 2008). This is a result of in part a lack of awareness of the wider histories and dynamics underpinning contemporary migration. In particular, as Feldman argues, "Current debates do not typically reflect or address Ireland's role in the global histories that contribute to migration including the circumstances that lead people to migrate and choose Ireland as a destination" (2008, p. 4).

The discursive challenge for pro-migrant groups is to frame the interests of beneficiaries who are too weak to make autonomous demands on the state as part of the broader concern of the host society (Statham 2003). ${ }^{30}$ In other words, promigrant engagement with the discursive political opportunity structure is aimed at introducing a definitional change within political discourse so that the interests of the beneficiary are defined as part of the common public good (Statham 2003). The ICI and MRCI have invested in discursive strategies in a competitive field where they must provide counter-frames to those employed by politicians and other actors who promote racialized anti-immigrant frames for public consumption. Movement frames are most successful if they are visible and perceived as resonant and legitimate by a sufficiently large public constituency (Statham 2001, p 138). Promigrant NGOs face the difficult task of introducing what have been termed as frame alignment processes (Snow 2004) into a hostile institutional political environment. Faced with the difficult task of attempting to link the interests of a weak and

\footnotetext{
${ }^{29}$ Most recently the ICI launched a series of workshops aimed at educating migrant leaders on communication, fundraising, and social entrepreneurial skills.

${ }^{30}$ Framing refers to the ideological pronouncements of NGOs with which they assign meaning to and interpret relevant events and conditions to garner bystander support and demobilize antagonists. Frames also refer to the actions of NGOs, as encoded in the actions and strategies of groups are messages which can influence supporters (McAdam et al. 1996, p. 341).
} 
stigmatized beneficiary to the perceived interests of other actors has led both organizations to deploy a series of framing efforts aimed at normalizing their constituents and creating resonance between the struggles migrants face and those experienced by members of the general public.

In more specific terms, both organizations employ what social movement scholars have labeled diagnostic, prognostic, and motivational frames. MRCI's use of a case management database allows them to provide what they term as evidence based analyses of the migrant experience in Ireland. Data culled from their database are used for diagnostic framing to establish the frequency of migrants experiencing a range of problems related to employment, residency status, access to education and social welfare. These data are communicated directly to politicians and public officials and used in leaflets including "Myths and Misinformation about Migrant Workers and their Families," distributed to the general public. The MRCI also engages in prognostic framing, which has a stronger normative dimension but rests firmly on suggestions for policy change.

The MRCI bridging visa campaign is an example of a combination of these strategies. It combines materials to quantify the number of migrants becoming undocumented through employer exploitation and then sets out a series of legislative and policy proposals to establish an intermediary visa status to allow migrants to retain residency status while they seek new employment. After a series of low key mobilizations with civil servants a call for a bridging visa has become part of policy debates around managing migration (NESC 2006; ICTU 2006; MRCI 2007b).

Motivational framing has the strongest normative dimension and is used to mobilize a counter set of norms in a political discourse through the identification of a perceived injustice (Statham 2003). Motivational framing often deploys moralizing frames to amplify the human rights obligations of the state. MRCI and ICI have drawn on individual testimony of migrants featured in newspaper coverage and on television and radio to represent migrants as regular people facing hardships. Both organizations have worked to reframe migrants as sharing concerns and challenges that are similar to those of the indigenous population. The MRCI placed a front page feature in the national media on the story of a young migrant with a dependent family who worked in the mushroom picking industry and who experienced exploitation and harsh working conditions to communicate the human face of immigration. In this way worker exploitation is framed as a common problem with consequences for all Irish workers and is matched with statements from migrant's declaring their appreciativeness for the opportunity to participate and contribute to Irish society. The MRCI also supported a multi-media art exhibition depicting the lives of Migrant Domestic Workers. The event, launched on International Women's Day in March 2007 in a Dublin city art gallery, drew politicians, celebrities, and considerable media coverage. In addition, a primetime documentary produced by the NGO compared the experiences of Irish illegal immigrants in the USA with those undocumented in Ireland, with the objective of encouraging the public to identify with the commonality of immigration as a globally shared reality and to highlight the hypocrisy of the Irish government's lobby for the legalization of undocumented Irish abroad while denying such concessions to immigrants on its own soil. The later media strategy gained 
widespread coverage and resulted in an agreement from the Department of Enterprise and Trade (DETE) to consider cases from undocumented workers with significant lapse in their legal status to renew applications for work permits.

The ICI has also invested in what the director describes as a "champion strategy," using celebrities, including the American actor Martin Sheen and the former Irish President Mary Robinson, to represent the organization and its campaigns in the public domain. The director of the ICI appears regularly on national media to advance the case for reform of immigration policy. Editorials in the preeminent Irish newspaper, the Irish Times, also reference the ICI's research in their occasional commentaries on the public's response to immigrants and proposed reforms of Irish immigration policy (Irish Times 2008).

\section{International Opportunity Context}

Reacting to a restrictive immigration regime the ICI and MRCI do pressure the state to comply with international legal instruments. The MRCI participated in the UN migration dialogue held in New York in 2006. ${ }^{31}$ The Council of Europe 2006 Resolution on the human rights of irregular migrants and the UN Convention on Rights of Migrants are also key documents these NGOs reference in their lobbying work. To date the Irish government has not signed on to any of these international legal instruments. ${ }^{32}$

Efforts to push the state to adhere to its international commitments provided the impetus for a notable if rare strategic NGO collaboration. A coalition of NGOs, the NGO Alliance comprised of 44 organizations including the ICI, MRCI, human rights organizations, and a handful of migrant led groups provided a critique of the Irish government's denial of the existence of racism in its 2004 report to the UN Committee on the Elimination of Racial Discrimination (CERD). This NGO coalition submitted a shadow report to CERD which was positively received by the UN committee and subsequently incorporated into the UN's review of the Irish case. In reaction, the Irish government sent an unprecedented number of officials to Geneva to counter the NGO shadow analysis but were unsuccessful in convincing the committee of their case. A UN backed monitoring committee was also established with NGO representatives to report on the Irish governments' progress on meeting the CERD recommendations. These include establishing clear competency in Irish law to prosecute for race based hate crimes, to officially recognize the indigenous Traveller community as an ethnic minority, provisions for the integration of asylum seekers, and strengthened mechanisms to address racial

\footnotetext{
31 Other international legal instruments that these organizations pressure the government to comply with include the European Convention on Human Rights, Article 8 on the rights of the child, and Article 7 of the EU charter of fundamental rights.

32 The director of the MRCI also sits on the board of the European Network Against Racism (ENAR) a Brussels-based nongovernmental organization advocating for antiracism, antidiscrimination, and the rights of migrants and asylum seekers. Both the MRCI and ICI belong to the Platform for International Cooperation on Undocumented Migrants (PICUM) and the European Platform of Migrant Workers. These transnational organizations also advocate for the adoption of the 1990 UN International Convention on the Protection of Rights of Migrant Workers and members of their families.
} 
and ethnic discrimination in employment and in the provision of public services (Warner 2006).

The campaign on CERD represented a unique opportunity to collaborate on a transversal issue relevant to a range of NGOs but far removed from the micro political concerns of the domestic context. While EU policy on immigration is also an important point of reference for Irish NGOs working for the rights of migrants, asylum seekers, and refugees, most activists acknowledge the weak and restrictive nature of EU based initiatives. As the director of the Immigrant Council stated, "Sometimes the European Perspective is not what we are aspiring to" (interview with director of the ICI, July 12, 2007).

The MRCI is the host for the Irish chapter of the European Network Against Racism, and both NGOs work with the Brussels based Platform for Cooperation on Undocumented Migrants and the Brussels based women's rights organization the European Women's Lobby, which has invested in advocating for migrant women. Both the ICI and the MRCI connect to these international organizations which have longer traditions in advocating for migrants rights and the resources in relative terms to lobby the European institutions and by extension the Irish government. The European Court of Justice is also an important reference point for the ICI, which currently has a number of cases contesting Irish policy on immigration rights pending with the Court. International strategies are seen by both directors as important elements in their strategic repertoire but to date have yielded victories of a primarily symbolic importance.

\section{Building Capacity for Migrant Led NGOs}

In concrete terms migrant led groups have emerged to administer language classes, organize cultural activities, run drop-in centers, and commission research (Feldman 2007, pp. 200-202). ${ }^{33}$ Contrary to assumptions that these organizations lack expertise, leaders and members were found to be well educated, with relevant experience and training for the task of running such organizations (Feldman et al. 2005; Feldman 2007). Yet access for migrant led NGOs to policy setting arenas is complicated by majority-led NGOs and policy makers' perceptions of them as unrepresentative, disorganized, divided and weak (Spencer 2006, p. 42). Nevertheless, as discussed above majority led NGOs rely on migrants to inform their policy work and to mobilize their migrant constituencies. However, majority-led NGOs remain the main recipients of funding and the gatekeepers to resources available to work on these issues. For example, in January 2007 of 100 applicants for a $€ 5$ million government integration fund, 22 NGOs were chosen. However, none were migrant led or ethnic minority organizations. Migrant led organizations have as a result found it difficult to build the capacity and credibility required to secure funding (Feldman 2007). Public officials and foundations also lack a familiarity with and correspondingly trust of the migrant led sector. Moreover as Feldman's

\footnotetext{
33 Filipinos took the lead on work place rights and the issue of family reunification for Filipino nurses and physicians. African activism is often church based and local level around anti-racist programs. The later example of mobilization has been facilitated in part by the linguistic affinity between many Africans and the host society (see Ugba 2005).
} 
study of migrant led NGOs suggests, groups have emerged as a response to immediate needs on the ground and as a result have had insufficient time to develop the apparatus, such as strategic plans, often required by funding agencies (Feldman 2007, pp. 204-205).

A 2006 survey of the participation of African immigrants in civil society groups found an over involvement of elite representatives from the new communities. The report also found a tendency of majority led NGOs to recruit ethnic minorities as volunteers rather than paid employees (Ejorh 2006, p. 21). This said, the relationship between migrant and majority led organizations and the implications of this relationship for the quality of representation available to these constituents is a complex one (Spencer 2005). I argue that majority led organizations do value migrant input and have provided resources and expertise to migrants interested in developing their own organizations. Leadership programs provided by the MRCI and the ICI are a case in point. However, I also suggest that activists in majority led groups are not always confident in the ability of migrant led groups to provide effective input or build meaningful partnerships with their organizations. The division of labor which has arisen between majority led pro-migrant NGOs and the state also shifts NGO strategies towards insider tactics and may work to produce a form of radical flank effect wherein majority led organizations are perceived by the state and funders as the least contentious representatives of these communities.

Irish Anti-Racism, Migrant Advocacy, and Interculturalism

To understand the majority-led NGO response to migrants, asylum seekers, and refugees it is also important to assess previous work within the NGO sector on antiracism. Lentin (2007) argues that while the experience of the Irish as emigrants has been used by pro-migrant NGOs to counter contemporary racism against immigrants to Ireland, it is anti-Traveller racism which represents the most important impetus for the development of anti-racist strategies in Ireland. State policies towards the Traveller community in Ireland, a long discriminated and socially excluded indigenous ethnic minority, have become the template for dealing with the migrant population (see Fanning 2007a, pp. 237-244). The thrust of political responses to Travellers remains assimilationist (Lentin 2006a, b; Watt 2006). While efforts to promote Travellers rights have improved the profile of this community, Lentin suggests that the Traveller support movement, built upon a community development model has recreated the dependence of Travellers on the "settled" population. According to Lentin, activists have categorized Travellers as lacking the capacity to represent themselves. A failure to transfer power and resources to this minority ethnic constituency is now Lentin suggests duplicated in the emerging architecture of NGO advocacy groups for immigrant, refugee, and asylum seekers (Lentin 2006a, b).

Despite such criticism, the pro-migrant NGOs discussed here do espouse a commitment to the practice of interculturalism. This term has been broadly adopted by policy makers, NGOs, and intergovernmental organizations such as the EU which designated 2008 "Europe Year of Intercultural Dialogue." Interculturalism has been defined loosely as suggestive of an interactive exchange, framed in large 
part on the so-called Canadian approach to the integration of immigrants and ethnic minorities. In other words, interculturalism is considered a third way between assimilationist and multiculturalists paradigms, with a focus on support for inclusive and equal interaction between host society and new communities (Watt 2006). ${ }^{34}$ For NGOs an intercultural approach is suggestive of efforts to engage migrants, asylum seekers, and refugees in organizational activities, specifically in the solicitation of input to policy submissions, provision of leadership training to facilitate migrant led activism, and more broadly in the use of community development strategies to provide services and support. In practice I suggest that while majority led NGOs subscribe in ideological terms to service and advocacy imbued with commitments to an intercultural agenda, in real terms they are less supportive of independently initiated migrant led activism. In effect majority led NGOs are most comfortable supporting migrant led mobilization originating from their own organizational programs. A strategy it seems which can be understood as a reaction to a constrained political and funding context but which falls short of the interactive exchange suggested by an intercultural approach.

\section{Conclusion}

Analysis suggests that the governance of immigration in Ireland has been focused on the management of a period of rapid economic change with little emphasis on the social implications of these shifts (Fanning and Mutwarasibo 2007). Politicians and policy makers have been slow to acknowledge the need for systematic institutional level planning to meet the needs of the new communities. The vacuum created by a lack of meaningful political debate on immigration has also allowed media and political discourse defining migrants, asylum seekers, and refugees as problematic to take root (MacCormaic 2007, 2008).

Policy developments including the introduction of the first comprehensive legislation on immigration in Ireland, the Immigration and Residence Bill 2008, reflects the state's partial acknowledgement of the migrant population and the incapacity of majority institutions to accommodate the increasing diversity of the Irish population. This legislation proposes to increase the discretion of the minister for Justice on immigration and asylum matters and to support the automatic and immediate deportation of undocumented persons without notice (DJELR 2007). The bill does not contain any provisions on the right to family reunification, yet does introduce a requirement for non-citizens to carry identification cards. The legislation also lacks any reference to the integration needs of migrants and their families. NGO analysis of this legislation suggests that it is in potential breach of not only the Irish constitution but also international human rights conventions.

While the Irish state has failed to adopt a number of international laws relating to human rights and racism it has invested in what has been termed as an

\footnotetext{
${ }^{34}$ In concrete terms the Irish state has outlined its understanding of interculturalism in practice, this includes recruitment of ethnic minorities to the police force, a review of criminal legislation to combat hate-crime, strategies to encourage participation by young immigrants in sport and the promotion of awareness of the cultures and histories of the new arrivals (see Watt 2006).
} 
"interculturalism industry" limited to language classes and some efforts to diversify the police force (Lentin 2006a, b; Loyal 2007, pp. 129-30). Finding ways of securing broader participation of new communities in societal, economic, and political processes has been devolved to individual immigrants and by default majority led pro-migrant NGOs. This research suggests that this task is complicated by the narrow political terrain for NGOs working on immigration issues and while some modest success has been achieved on labor market issues, NGO mobilization on long term residency, family reunification, and a more transparent and rights based approach to asylum and refugees have proven less successful.

Pro-migrant NGOs do face particular challenges: a lack of receptiveness to their proposals from policy makers who remain committed to a restrictive immigration model; the predominance of a racialized public and political discourse around immigration; and their relationships with state bodies, seen by many migrant led NGOs as instigators of racism. Pro-migrant NGOs have in response developed a strategic repertoire aimed at influencing institutional and discursive opportunity structures. First they have created their own alliance structure composed of nonstate actors including trade unions and anti-poverty and women's rights NGOs who are increasing open to the challenges posed by immigration for their indigenous constituents and the new communities. State bodies made up of sympathetic public officials and dependent on NGOs for information and service provision have also proven important allies. Pro-migrant NGOs have also resorted to international political contexts including the EU and the UN in their efforts to shame the Irish state for its poor record in participating in international commitments to protect the rights of migrants, refugees, asylum seekers, and their families. Thirdly, pro-migrant NGOs have engaged the discursive opportunity structure, countering state and media discourse on immigration with depictions of migrants as deserving and at times vulnerable individuals.

While pro-migrant NGOs can claim a form of inclusion in policy setting processes such as social partnership, access in itself does not guarantee influence. Lentin's (2007) critique of the community development approach adopted by promigrant NGOs draws needed attention to the limits of this form of mobilization. However, her critique of majority led pro-migrant NGOs requires qualification. Promigrant NGOs are committed to an anti-racist and, in time, I suggest a more participatory version of interculturalism. However, the political opportunity structure and specifically pressure for resources complicates their efforts to be more inclusive of migrant led organizations. The physical location of the organizations detailed above - the capital city Dublin - also hinders access and communication with smaller migrant led NGOs working in rural contexts.

The role of the state, its policy perspectives on immigration and integration, and its marginalizing tradition of interaction with NGOs are then key issues in making sense of the challenges facing NGO mobilization on migrants rights in Ireland. State policies which racialize migrants, asylum seekers, and refugees, while denying the existence of endemic racism render more radical anti-racist and intercultural forms of NGO mobilization and coalition building difficult to employ. Most recently, as Loyal (2007) argues the waning of spectacular economic growth coupled with decaying public services has worked to encourage anti-immigrant sentiment within 
marginalized and middle class communities alike. A coherent and solidaristic approach across the NGO sector and between majority and migrant led NGOs is I suggest a requisite to counter dominant anti-immigrant discourse and push for the extension of political, social, and economic rights to migrants, asylum seekers, and refugees.

Acknowledgments This research was supported by research and development funds at Dickinson College. Thanks to Professor Daniel Schubert and Professor Brian A. McKenzie and two anonymous Voluntas reviewers for helpful suggestions.

\section{References}

Allen, K. (2007). Double speak: Neo-liberalism and migration. In B. Fanning (Ed.), Immigration and social change in the Republic of Ireland (pp. 84-98). Manchester: Manchester University Press.

Amnesty International Ireland. (2006). Annual report on Ireland. Dublin: Amnesty International. Anderson, C., \& O'Brien, N. (2006, April 4). Beyond the European social model. EU Observer. Bacik, I. (2004). Kicking and screaming: Dragging Ireland into the 21st century. Dublin: O'Brien Press. Bartley, B., \& Kitchin, R. (Eds.). (2007). Understanding contemporary Ireland. London: Pluto Press. Beesley, A. (2004, June 10). Vulnerable women blamed for maternity cutbacks. The Irish Times.

Begg, D. (2007). Immigration, integration and cultural identity. Translocations: The Irish Migration, Race and Social Transformation Review, 2(1), 181-189.

Beirne, L., \& Jaichand, V. (2006). Breaking down barriers: Tackling racism in Ireland at the level of the state and its institutions. Amnesty International Ireland and the Irish Centre for Human Rights, National University of Galway.

Boucher, G. (2007). Review of International Organisation for Migration (2006) and Managing Migration in Ireland: A social and economic analysis-National Economic and Social Council (2006) migration policy. Translocations: The Irish Migration, Race and Social Transformation Review, 2(1), 199-201.

Boucher, G. (2008). Ireland's lack of a coherent integration policy. Translocations: The Irish Migration, Race and Social Transformation Review, 2(1), 1-24.

Brandi, S. (2007). Unveiling the ideological construction of the 2004 Irish Citizenship Referendum: A critical discourse analytical approach. Translocations: The Irish Migration, Race and Social Transformation Review, 2(1), 26-47.

Central Statistics Office. (2004). Population and migration estimates. Dublin: Stationary Office.

Central Statistics Office. (2006). Population and migration estimates. April 2003, April 2005 and Sept 2006. Dublin: Stationary Office.

Central Statistics Office of Ireland. (2004). Quarterly National Household Survey; Equality Quarter 4. Dublin: Stationary Office.

Chadamoyo, N., Fanning, B., \& Mutwarasibo, F. (2007). Getting into politics. In B. Fanning (Ed.), Immigration and social change in the Republic of Ireland (pp. 185-197). Manchester: Manchester University Press.

Conroy, P. (2003, March 21). Migrant women-Ireland in the international division of care. Paper presented at the "Women's movement: Migrant women transforming Ireland" conference, Trinity College, Dublin.

Coulter, C., \& Coleman, S. (Eds.). (2003). The end of Irish history. Manchester: Manchester University Press.

Council of Europe. (2006). European Commission Against Racism and Intolerance Country Report on Ireland. www.coe.int/t/e/human\%5Frights/ecri/

Crowley, U., Glimartin, M., \& Kitchin, R. (2006). Vote Yes for Common Sense Citizenship: Immigration and the paradoxes at the heart of Ireland's Cead Mile Failte. Maynooth working paper series no. 30, National Institute for Regional and Spatial Analysis, National University of Ireland.

Cullen, P. (2008). Irish women's organizations in an enlarged Europe. In R. Silke (Ed.), Gender politics in the expanding European Union: Mobilization, inclusion, exclusion (pp. 83-100). London: Berghahn Press. 
Daly, S. (2008). Mapping civil society in the Republic of Ireland. Community Development Journal, 43(2), 157-176.

Department of Justice, Equality, Law Reform. (2007). Immigration and residence in Ireland-Outline proposals for an Immigration and Residence Bill: A discussion document. Dublin: Department of the Taoiseach.

Department of the Taoiseach. (2006). Towards 2016 Social Partnership Agreement 2006-10. Dublin: Department of the Taoiseach.

EAPN Ireland. (2007). Fact sheet on the integration of new communities. Dublin: EAPN.

Edwards, B., \& McCarthy, J. D. (2004). Resources and social movement mobilization. In D. Snow, S. Soule, \& H. Kreisi (Eds.), Blackwell companion to social movements (pp. 116-152). Oxford: Blackwells.

Ehrenreich, B., \& Hochschild, R. A. (2003). Global women: Nannies, maids and sex workers in the new economy. London: Metropolitan Books.

Ejorh, T. (2006). Inclusive citizenship in 21st century Ireland: What prospects for the African immigrant community? Dublin: Africa Solidarity Centre.

European Commission. (2006). A common agenda for integration framework for the integration of thirdcountry nationals in the European Union COM (2005) 389 final. Brussels: EC.

Fahey, T., Russell, H., \& Whelan, C. T. (Eds.). (2007). The best of times? The social impact of the Celtic Tiger in Ireland. Dublin: Institute of Public Administration; Dordrecht: Springer.

Fanning, B. (Ed.). (2007a). Immigration and social change in the Republic of Ireland. Manchester: Manchester University Press.

Fanning, B. (2007b). Racism rules and rights. In B. Fanning (Ed.), Immigration and social change in the Republic of Ireland (pp. 6-26). Manchester: Manchester University Press.

Fanning, B. (2007c). Integration and social policy. In B. Fanning (Ed.), Immigration and social change in the Republic of Ireland (pp. 237-258). Manchester: Manchester University Press.

Fanning, B. (2007d). Social partnership and the politics of immigrant worker protection. Paper presented to "The unprotected migrant: Mobility, social policy and labour rights in Europe" conference, Tampere, Finland.

Fanning, B., \& Mutwarasibo, F. (2007). Nationals/non-nationals: Immigration, citizenship and politics in the Republic of Ireland. Ethnic and Racial Studies, 30(3), 439-460.

Feldman, A. (2007). Immigrant civic mobilisation. In B. Fanning (Ed.), Immigration and social change in the Republic of Ireland (pp. 198-213). Manchester: Manchester University Press.

Feldman, A. (2008). Integration-Mapping the terrain. Translocations: The Irish Migration, Race and Social Transformation Review, 2(1), 1-9.

Feldman, A., Ndakengerwa, D. L., Nolan, A., \& Frese, C. (2005). Diversity, civil society and social change in Ireland: A north-south comparison of the role of immigrant/"new" minority ethnic-led community and voluntary sector organisations. Geary Institute, University College Dublin.

Geoghegan, M., \& Powell, F. (2006). Community development, partnership governance and dilemmas of professionalization: Profiling and assessing the case of Ireland. British Journal of Social Work, 36(5), 845-861.

Grey, B. (2006). Migrant integration policy: A nationalist fantasy of management and control? Translocations: The Irish Migration, Race and Social Transformation Review, 1(1), 121-141.

Guigni, M., \& Passy, F. (2004). Migrant mobilization between political institutions and citizenship regimes: A comparison of France and Switzerland. European Journal of Political Research, 43(1), 51-82.

Hughes, G., McGinnity, F., O’Connell, P., \& Quinn, E. (2007). The impact of immigration. In T. Fahey, H. Russell, \& C. T. Whelan (Eds.), The best of times? The social impact of the Celtic Tiger in Ireland (pp. 217-244). Dublin: Institute of Public Administration; Dordrecht: Springer.

Imig, D., \& Tarrow, S. (2001). Contentious Europeans: Protest and politics in an emerging polity. Lanham, MD/Oxford: Rowman and Littlefield.

Immigrant Council of Ireland. (2003). Labour migration into Ireland: Study and recommendations on employment permits, working conditions, family reunification and the integration of migrant workers in Ireland. Dublin: The Immigrant Council of Ireland.

Immigrant Council of Ireland. (2004). Voices of immigrants: The challenges of inclusion. Dublin: The Immigrant Council of Ireland.

Immigrant Council of Ireland. (2007a). Annual report 2006. Dublin: ICI.

Immigrant Council of Ireland. (2007b). Bulletin. Dublin: ICI.

Interview with the Acting Director of the Migrants Rights Centre of Ireland, June 21, 2007. 
Interview with the Director of the Immigrant Council of Ireland, July 31, 2007.

Irish Congress of Trade Unions. (2006). Homes and workplaces: The rights of domestic workers. www.ictu.ie/campaigns/2006

Irish Congress of Trade Unions. (2006). Equal rights for agency workers. www.ictu.ie/campaigns/

Irish Congress of Trade Unions. (2008). Observations and Recommendations on the immigration. Residence and Protection Bill 2008. www.ictu.ie/download/pdf/immigration_bill_apr_08.pdf

Irish Refugee Council. (2007). UNHCR Statistics for asylum applications in 50 industrialised countries in 2006. www.irishrefugeecouncil.ie/press07/unhcr.html

Joachim, J. (2007). Agenda setting the UN and NGOs: Gender violence and reproductive rights. Washington, DC: Georgetown University Press.

Joachim, J., \& Locher, B. (2008). Transnational activism in the UN and the EU. London: Routledge.

Kirby, P., Gibbons, L., \& Cronin, M. (2002). Introduction. The reinvention of Ireland: A critical perspective. In P. Kirby, L. Gibbons, \& M. Cronin (Eds.), Reinventing Ireland: Culture, society and the global economy (pp. 1-20). London: Pluto Press.

Koopmans, R., \& Statham, P. (1999). Challenging the liberal nation-state? Postnationalism, multiculturalism, and the collective claims making of migrants and ethnic minorities in Britain and Germany. American Journal of Sociology, 105(3), 652-696.

Kreisi, H. (2004). Political context and opportunity. In D. Snow, S. Soule, \& H. Kreisi (Eds.), Blackwell companion to social movements (pp. 67-90). Oxford: Blackwells.

Lentin, R. (2006a). Migrant women's networks and intercultural Ireland. Discussion paper no. 148, Institute of International Integration Studies, Trinity College Dublin.

Lentin, A. (2006b). Anti-racism in Ireland. In L. Connolly \& N. Hourigan (Eds.), Social movements and Ireland (pp. 190-209). Manchester: Manchester University Press.

Lentin, R. (2007). Ireland: Racial state and crisis racism. Ethnic and Racial Studies, 30(4), 610-627.

Lentin, R., \& McVeigh, R. (2006a). Irishness and racism: Towards an e-reader. Translocations: The Irish Migration, Race and Social Transformation Review, 1(1), 22-40.

Lentin, R., \& McVeigh, R. (2006b). After optimism? Ireland, racism and globalisation. Dublin: Metro Eireann Publications.

Loyal, S. (2007). Immigration. In S. O’Sullivan (Ed.), Contemporary Ireland: A sociological map (pp. 30-47). Dublin: University College Dublin Press.

Mac Éinrí, P. (2007a). Integration models and choices. In B. Fanning (Ed.), Immigration and social change in the Republic of Ireland (pp. 214-236). Manchester: Manchester University Press.

Mac Éinrí, P. (2007b). Immigration: Labour issues, asylum seekers and refugees. In B. Bartley \& R. Kitchin (Eds.), Understanding contemporary Ireland (pp. 236-248). London: Pluto Press.

MacCormaic, R. (2007, March 5). Immigration, the issue that dare not speak its name. The Irish Times. www.irishtimes.com

MacCormaic, R. (2008, July 3). Losing our immigrants in a fog of vague intentions. The Irish Times. www.irishtimes.com

McAdam, D. (1996). Political opportunities: Conceptual origins, current problems, future directions. In D. McAdam, J. McCarthy, \& M. Zald (Eds.), Comparative perspectives on social movements (pp. 23-40). New York: Cambridge University Press.

McAdam, D., McCarthy, J., \& Zald, M. (Eds.). (1996). Comparative perspectives on social movements (pp. 1-22). New York: Cambridge University Press.

McGinnity, F., O’Connell, P., Quinn, E., \& Williams, J. (2006). Migrants experience of racism and discrimination in Ireland. Dublin: ESRI.

Meade, R. (2005). "We hate it here, please let us stay!" Irish social partnership and the community/ voluntary sector's conflicted experiences of recognition. Critical Social Policy, 25(3), 349-373.

Menz, G. (2008). The political economy of managed migration. Oxford: Oxford University Press.

Migrant Rights Centre of Ireland. (2004a). Work permits in Ireland: A recommendation for change. Dublin: MRCI.

Migrant Rights Centre of Ireland. (2004b). Private spaces: A public concern-The experiences of migrant woman employed in the private home. Dublin: MRCI.

Migrant Rights Centre of Ireland. (2007a). Annual report 2006. Dublin: MRCI.

Migrant Rights Centre of Ireland. (2007b). Bridging visa campaign. Dublin: MRCI.

Migrant Rights Centre of Ireland. (2008). Restaurant workers action group: Exploitation in Ireland's restaurant industry. www.mrci.ie/documents/Exploitation_in_Irelands_Restaurant_Industry_Dec_ 08.pdf 
Murphy, M. (2002). Social partnership-Is it "the only game in town?" Community Development Journal, 37(1), 80-90.

National Consultative Committee on Racism and Interculturalism. (2007). The National Action Plan Against Racism-A strategy guide for community development projects. Dublin: Family Resource Centres and Partnerships, NCCRI.

National Economic Social Council. (2006). Migration policy. Report no. 115. Dublin: NESC.

National Economic Social Forum. (2007). Improving the delivery of quality public services. Dublin: NESF.

National Women's Council of Ireland. (2007). ENews Letter September 2007. Dublin: NWCI.

Niessen, J., Huddleston, T., Citron, L., Geddes, L. A., \& Jacobs, D. (2007). Migration Integration Policy Index: Country profile Ireland (pp. 106-111). British Council and Migration Policy Group.

O'Brien, C. (2008, July 25). ECJ ruling welcomed by immigrant groups The Irish Times. www. irishtimes.com

Office of the Refugee Applications Commissioner. (2007). www.orac.ie/pages/Stats/statistics.htm

Phelan, M. (2006). Interpreting services in Ireland: Setting standards and establishing systems. Spectrum, 12, 7-9.

Pillinger, J. (2006). An introduction to the situation and experience of women migrant workers in Ireland. Dublin: The Equality Authority.

Pobal. (2007). Press release, www.pobail.ie/en/communityvoluntarysupports/whitepaperoncommunity andvoluntaryactivity

Quinn, E., \& Hughes, G. (2004). The impact of immigration on Europe's societies: Ireland. Report prepared for the European Commission Directorate-General Justice, Freedom and Security and published by the Economic and Social Research Institute.

Ruhs, M. (2005). Managing the immigration and employment of non-EU nationals in Ireland. Oxford: Policy Institute and Trinity College Dublin in association with Compas.

Slattery, L. (2008, December 2) Exchequer deficit set to exceed 11.5 billion euro in 2008. The Irish Times. www.irishtimes.com

Snow, D. A. (2004). Framing processes, ideology, and discursive fields. In D. Snow, S. Soule, \& H. Kreisi (Eds.), Blackwell companion to social movements (pp. 380-412). Oxford: Blackwells.

Spencer, S. (2005). Towards a European area of freedom, security and justice? A common framework for the integration of migrants. European Policy Centre Issue 14. www.theepc/ern/default.asp

Spencer, S. (2005/6). Migration and integration: The impact of NGOs on future policy development in Ireland. Center on Migration Policy and Society, University of Oxford.

Statham, P. (2001). Political opportunities for altruism? The role of state policies in influencing British anti-racist and pro-migrant movements. In M. Giugni \& F. Passy (Eds.), Political altruism? Solidarity movements in international perspective (pp. 133-158). New York/Oxford: Rowman and Littlefield Press.

Statham, P. (2003). Understanding the anti-asylum rhetoric: Restrictive politics or racist publics? Political Quarterly, 74(1), 163-177.

Statham, P., \& Geedes, A. (2006). Elites and organized publics: Who drives British immigration politics and in which direction? Western European Politics, 29(2), 245-266.

Statham, P., \& Gray, E. (2005). Becoming European? The transformation of the British pro-migrant NGO sector in response to Europeanization. Journal of Common Market Studies, 43(4), 877-898.

Statham, P., \& Koopmans, R. (2003). How national citizenship shapes transnationalism: A comparative analysis of migrant and minority claims-making in Germany, Great Britain and the Netherlands. In C. Joppke \& E. Morawska (Eds.), Toward assimilation and citizenship: Immigrants in liberal nation-states (pp. 195-238). London: Palgrave.

Ugba, A. (2005). Active civic participation of immigrants in Ireland. Country report prepared for the European research project POLITIS, Oldenburg, Germany. www.unioldenburg.de/politis.europe

United Nations High Commissioner for Refugees (UNHCR). (2008). Statement to the Dail Joint Committee on Justice, Equality, Defence and Women's Rights, April 2 2008. www.oireachtas.ie/ documents/committees30th dail/j-justiceedwr/reports_2008/

Warner, R. (2006). The NGO alliance and CERD: How Irish NGOs can work with a UN monitoring body. Translocations: The Irish Migration, Race and Social Transformation Review, 1(1), 164-176.

Watt, P. (2006). An intercultural approach to "integration." Translocations: The Irish Migration, Race and Social Transformation Review, 1(1), 154-163.

White, R. (2008). Research report: Irish economy. Davy Research. www.davy.ie/content/pubarticles/ dotlecr20081204.pdf 
Reproduced with permission of the copyright owner. Further reproduction prohibited without permission. 